\title{
Analisis Kemampuan Representasi Matematis Siswa berdasarkan Tingkat Motivasi Belajar pada Pandemi Covid-19
}

\author{
Jasmine Salsabila Lutfi ${ }^{1}$, Hikmatul Khusna ${ }^{2}$ \\ 1,2 Pendidikan Matematika, Fakultas Keguruan dan Ilmu Pendidikan, Universitas Muhammadiyah Prof. Dr. HAMKA \\ J1. Tanah Merdeka No 20, Jakarta Timur, Indonesia \\ jasmine.salsabila2@gmail.com
}

\begin{abstract}
Students are expected to have high learning motivation during the Covid-19 pandemic. So, they are able to have good mathematical thinking skill. One of the important mathematical thinking skills is the mathematical representation ability. The purpose of this research is to describe the ability of mathematical representation based on the level of learning motivation in the Covid-19 pandemic. The method used is qualitative approach with descriptive method. The research subjects numbered 2 people from 36 students of grade XI MIPA 3 at MAN 9 Jakarta in the even semester 2020/2021. Test, non-test, and interview techniques are used to collect research data. The instruments used include learning motivation questionnaires, mathematical representation ability tests, and interview guidelines. Miles and Huberman models are data analysis techniques used. The results found that none of the students were low-learning motivated. Mathematical representation ability in highly motivated students, can solve the problem of two-circle slice material well, although it does not meet 1 indicator that is verbal representation. Mathematical representation ability in students with moderate learning motivated, can solve the problem of two-circle slice material quite well because of inaccuracies, errors in answers, and does not meet 1 indicator that is verbal representation.
\end{abstract}

Keywords: Mathematical Representation Ability, Learning Motivation, Online Learning

\begin{abstract}
Abstrak
Siswa diharapkan memiliki motivasi belajar yang tinggi di masa pandemi Covid-19 sehingga mereka mampu memiliki keterampilan berpikir matematis yang baik. Salah satu keterampilan berpikir matematis yang penting yakni kemampuan representasi matematis. Tujuan dalam riset ini yaitu mendeskripsikan kemampuan representasi matematis siswa berdasarkan tingkat motivasi belajar pada pandemi Covid-19. Metode yang digunakan adalah pendekatan kualitatif dengan metode deskriptif. Subjek riset berjumlah 2 orang dari 36 siswa kelas XI MIPA 3 di MAN 9 Jakarta pada semester genap 2020/2021. Teknik non-tes, tes, dan wawancara digunakan untuk mengumpulkan data riset. Instrumen yang digunakan antara lain angket motivasi belajar, soal tes kemampuan representasi matematis, dan pedoman wawancara. Model Miles dan Huberman yaitu teknik analisis data yang digunakan. Hasil riset ditemukan bahwa siswa bermotivasi belajar tinggi, dan sedang pada pandemi Covid-19. Kemampuan representasi matematis pada siswa bermotivasi belajar tinggi, dapat menyelesaikan soal materi irisan dua lingkaran dengan baik, walaupun tidak memenuhi 1 indikator yaitu representasi verbal. Kemampuan representasi matematis pada siswa bermotivasi belajar sedang, dapat menyelesaikan soal materi irisan dua lingkaran dengan cukup baik karena adanya ketidaktelitian, kesalahan jawaban, serta tidak memenuhi 1 indikator yaitu representasi verbal.
\end{abstract}

Kata kunci: Kemampuan Representasi Matematis, Motivasi Belajar, Pembelajaran Daring

Copyright (c) 2021 Jasmine Salsabila Lutfi, Hikmatul Khusna

$\triangle$ Corresponding author: Jasmine Salsabila Lutfi

Email Address: jasmine.salsabila2@gmail.com (Jl. Tanah Merdeka No. 20, Jakarta Timur, Indonesia)

Received 21 June 2021, Accepted 25 July 2021, Published 02 August 2021

\section{PENDAHULUAN}

Penyebaran pandemi Covid-19 memiliki dampak pada pelaksanaan pendidikan di sekolah. Berdasarkan surat edaran dari Menteri Pendidikan dan Kebudayaan Republik Indonesia No. 4 tahun 2020, bahwa pembelajaran di sekolah dialihkan menjadi pembelajaran dari rumah secara daring (Kemdikbud, 2020). Proses pembelajaran dilaksanakan dari rumah secara daring untuk meminimalisir penyebaran Covid-19 pada warga sekolah. Pembelajaran daring menjadi tantangan bagi pelaksanaan pendidikan 
khususnya guru dan siswa. Motivasi belajar siswa menurun pada pembelajaran daring akibat pandemi Covid-19 (Cahyani et al., 2020). Jika pembelajaran di dalam kelas, guru dapat menerangkan perhitungan matematika, menjawab pertanyaan siswa yang masih belum dimengerti, dan saling berinteraksi secara langsung. Namun dalam pembelajaran daring, terdapat jarak antara guru dengan siswa sedangkan siswa harus memiliki kemampuan berpikir matematis.

Berdasarkan National Council of Teacher Mathematics, ada 5 keterampilan berpikir matematis yang patut dimiliki oleh siswa, yaitu kemampuan representasi, kemampuan pemecahan masalah, kemampuan penalaran, kemampuan komunikasi, dan kemampuan koneksi (NCTM, 2000). Di antara keterampilan berpikir matematis yang penting pada pembelajaran matematika yakni kemampuan reprentasi matematis. Kemampuan representasi dianggap penting untuk dimiliki agar siswa dapat memahami konsep matematika dengan baik (Hadi, 2018). Lebih lanjut, kemampuan representasi matematis juga penting karena memiliki hubungan yang erat dengan kemampuan komunikasi serta pemecahan masalah siswa (Khairunnisa et al., 2020). Dengan demikian, agar dapat menguasai konsep matematika, mengkomunikasikan ide-ide matematis, sampai akhirnya dapat menyelesaikan masalah matematika, dibutuhkan kemampuan representasi yang baik pada siswa terutama pada situasi saat ini.

Representasi yaitu alat yang mendukung untuk menemukan penyelesaian dari masalah dengan mengeksternalisasikan sesuatu yang ada di dalam pikiran yang bersifat abstrak (Sanjaya et al., 2018). Representasi adalah cara untuk meraih suatu konsep matematika ke dalam beberapa bentuk (diagram, grafik, dan simbol) (NCTM, 2000). Representasi matematis menjadi sebuah upaya siswa dalam memahami konsep, menyampaikan pemahamannya, serta mencari penyelesaian dari suatu permasalahan (Rangkuti, 2014). Representasi berguna sebagai alat untuk menyampaikan ide matematis dari siswa kepada guru maupun siswa lain. Dengan representasi, siswa menampilkan hasil kerjanya sebagai interpretasi dari pemikirannya.

Representasi umumnya dikelompokkan menjadi 2 bentuk, yakni representasi internal serta representasi eksternal. Bersumber pada Hiebert dan Chorpenter, representasi internal adalah suatu proses penyusunan ide-ide matematis yang melibatkan pengetahuan siswa dimana tidak bisa dilihat dengan kasat mata prosesnya dan tidak bisa dinilai dengan langsung. (Rangkuti, 2014; Sanjaya et al., 2018). Menurut Goldin (Mustangin, 2015), representasi eksternal yaitu hasil tampilan penggambaran yang dikerjakan seseorang secara internal yang dapat berupa verbal, gambar, dan benda konkrit. Bentuk representasi yang diamati dalam riset ini adalah representasi eksternal yang memiliki wujud berupa ekspresi matematis, teks tertulis, serta visual.

Indikator pada kemampuan representasi matematis antara lain ekspresi/persamaan matematis, representasi visual, serta teks tertulis/kata-kata (Herdiman et al., 2018). Pada riset ini, indikator kemampuan representasi matematis yang digunakan antara lain melibatkan ekspresi matematis dalam menyelesaikan masalah (representasi simbolik), menyelesaikan masalah dengan memanfaatkan visual/gambar (representasi visual), dan menguraikan langkah-langkah berupa kata-kata penyelesaian masalah matematika (representasi verbal). Kemampuan representasi matematis sangat dipengaruhi oleh 
motivasi belajar siswa karena motivasi menghasilkan keinginan yang kuat, dorongan keras, serta kecenderungan ingin segera meyelesaikan suatu masalah (Yenni, Sukmawati, 2020). Jika motivasi siswa cukup tinggi maka siswa akan memutuskan untuk melakukan kegiatan belajar dan menyelesaikan suatu masalah dengan representasi matematis.

Motivasi yakni dorongan besar yang menggerakkan seorang atau kelompok sehingga melakukan suatu aktivitas agar meraih tujuan yang diinginkan (Surifah et al., 2016). Motivasi belajar siswa muncul dari luar maupun dalam diri siswa, sebagai ketekunan agar meraih hasil belajar yang sebaik mungkin dalam kegiatan belajar. (Nirfayanti \& Nurbaeti, 2019). Dalam riset ini, indikator motivasi belajar yang digunakan berasal dari teori Uno (Ayu et al., 2019; Rahmawati, 2016) yaitu adanya kegiatan belajar yang menarik, adanya hasrat serta keinginan berhasil, adanya harapan terhadap cita-cita, adanya dorongan kebutuhan belajar, adanya lingkungan belajar yang kondusif, serta adanya penghargaan.

Motivasi belajar umumnya dikelompokkan menjadi 2 yaitu motivasi ekstrinsik, serta motivasi intrinsik. Motivasi intrinsik yaitu dorongan yang muncul dari dalam diri sehingga siswa melakukan tindakan belajar (Surifah et al., 2016). Contoh motivasi instrinsik yaitu seseorang yang senang mengerjakan soal-soal matematika di waktu luang bukan karena tekanan dari lingkungan tetapi karena kemauannya sendiri, sehingga tidak memerlukan dorongan dari orang lain. Motivasi ekstrinsik yakni dorongan yang muncul dari luar diri siswa sehingga mendorong siswa melakukan kegiatan belajar yang dipengaruhi oleh harapan keluarga, harapan guru, teman, dan insentif eksternal seperti imbalan dan hukuman (Surifah et al., 2016; Handayani, 2017; Hima, 2017). Contoh motivasi ekstrinsik yaitu seseorang belajar matematika untuk ujian bukan dengan tujuan mengetahui sesuatu melainkan agar mendapatkan pujian atau hadiah.

Berdasarkan riset terdahulu Khairunnisa et al. (2020) serta Yenni \& Sukmawati (2020), riset tersebut dilakukan sebelum pandemi Covid-19 serta subjek riset yang didominasi oleh siswa SMP dan mahasiswa. Sehingga pembaruan dalam riset ini yakni dilaksanakan pada pandemi Covid-19 serta subjek riset adalah siswa MA (Madrasah Aliyah). Selain itu, riset ini juga mengidentifikasi kecenderungan kemampuan representasi matematis yang digunakan siswa dalam menyelesaikan soal pada pandemi Covid-19. Dengan demikian, riset ini bertujuan untuk mendeskripsikan kemampuan representasi matematis siswa MA berdasarkan tingkat motivasi belajar rendah, sedang, dan tinggi pada masa pandemi Covid-19.

\section{METODE}

Riset ini memanfaatkan pendekatan kualitatif dengan metode deskriptif untuk mendeskripsikan kemampuan representasi matematis siswa dalam menyelesaikan soal materi irisan dua lingkaran. Riset ini dilaksanakan di MAN 9 Jakarta pada semester genap 2020/2021. Subjek riset berjumlah 2 orang dari 36 siswa kelas XI MIPA 3 di MAN 9 Jakarta pada semester genap 2020/2021. Subjek terdiri dari 1 siswa bermotivasi belajar sedang, dan 1 siswa bermotivasi belajar tinggi sebagai perwakilan pengambilan data yang diambil dengan teknik purposive sampling. Peneliti merupakan instrumen pengumpulan data yang 
utama dalam riset kualitatif (Sugiyono, 2018). Selain itu, peneliti dibantu dengan instrumen pengumpulan data berupa angket, tes, dan wawancara. Instrumen pengumpulan data telah divalidasi oleh 2 dosen pendidikan matematika Universitas Muhammadiyah Prof. Dr. HAMKA serta 1 guru matematika peminatan MAN 9 Jakarta sehingga layak digunakan untuk mengambil data di lapangan. Terdapat tiga tahapan analisis data berdasarkan model Miles dan Huberman (Sugiyono, 2018), yakni tahap reduksi data, tahap penyajian data, dan tahap penarikan kesimpulan.

\section{Angket Motivasi Belajar}

Angket dalam riset ini menggunakan skala Likert untuk mengidentifikasi motivasi belajar siswa yang disediakan dalam bentuk Google Form. Butir pernyataan terdiri dari 15 butir favorable (positif) dan 15 butir unfavorable (negatif) dengan 5 pilihan jawaban. Menurut Arifin (Yenni \& Sukmawati, 2020), pengkategorian motivasi belajar dihitung berdasarkan jumlah butir pernyataan dan pilihan jawaban. Pada riset ini, tingkatan motivasi belajar dibagi menjadi 3 tingkat yaitu motivasi belajar rendah, sedang, dan tinggi sesuai dengan tujuan riset. Didapatkan interval serta tingkatan motivasi belajar sebagai berikut:

Tabel 1. Interval serta Tingkatan Motivasi Belajar

\begin{tabular}{|c|c|}
\hline Interval & Tingkatan Motivasi Belajar \\
\hline $30-70$ & Rendah \\
\hline $71-110$ & Sedang \\
\hline $111-150$ & Tinggi \\
\hline
\end{tabular}

\section{Tes Kemampuan Representasi Matematis}

Tes uraian adalah tes yang digunakan untuk melihat kemampuan representasi matematis pada materi irisan dua lingkaran. Tes berisi 4 soal yang terdiri dari kemampuan representasi simbolik, kemampuan representasi verbal, representasi visual, serta kecenderungan representasi matematis yang digunakan siswa dalam menyelesaikan masalah. Tes disediakan dalam bentuk Google Form.

\section{Wawancara}

Wawancara dilakukan kepada perwakilan 1 siswa pada masing-masing tingkat motivasi belajar agar mengetahui bentuk representasi yang digunakan oleh siswa, serta menyesuaikan antara hasil jawaban siswa dengan kemampuan pemahaman siswa sebenarnya. Proses wawancara menggunakan Zoom Meeting.

\section{HASIL DAN DISKUSI}

\section{Hasil Motivasi Belajar}

Berikut adalah deskripsi data skor siswa XI MIPA 3 pada angket motivasi belajar:

Tabel 2. Ringkasan Hasil Skor Angket Motivasi Belajar

\begin{tabular}{|c|c|c|c|c|c|}
\hline Mean & Median & Modus & Minimum & Maximum & Sum \\
\hline 106,22 & 104,50 & 102 & 75 & 140 & 3824 \\
\hline
\end{tabular}

Berdasarkan tabel 2, nilai tengah atau median skor jawaban motivasi belajar siswa yaitu 104,50. 
Nilai modus atau frekuensi nilai yang paling banyak muncul yaitu 102. Nilai minimum pada skor jawaban motivasi belajar siswa yaitu 75. Sedangkan nilai maksimum pada skor jawaban motivasi belajar siswa adalah 140. Berdasarkan tabel 1 mengenai interval dan tingkatan motivasi belajar, tingkat motivasi belajar siswa berada di tingkatan rendah jika kurang dari 70. Karena nilai minimum skor jawaban motivasi belajar siswa 75 lebih dari 70, maka tidak ada siswa yang bermotivasi belajar rendah. Nilai mean atau rata-rata dari skor jawaban motivasi belajar siswa yaitu 106,22 yang memperlihatkan rata-rata motivasi belajar siswa berada di tingkatan sedang. Dengan demikian, motivasi belajar siswa kelas XI MIPA 3 berada di tingkatan sedang dan tinggi saja. Berikut ini adalah gambar diagram persentase tingkat motivasi belajar siswa kelas XI MIPA 3 di MAN 9 Jakarta:

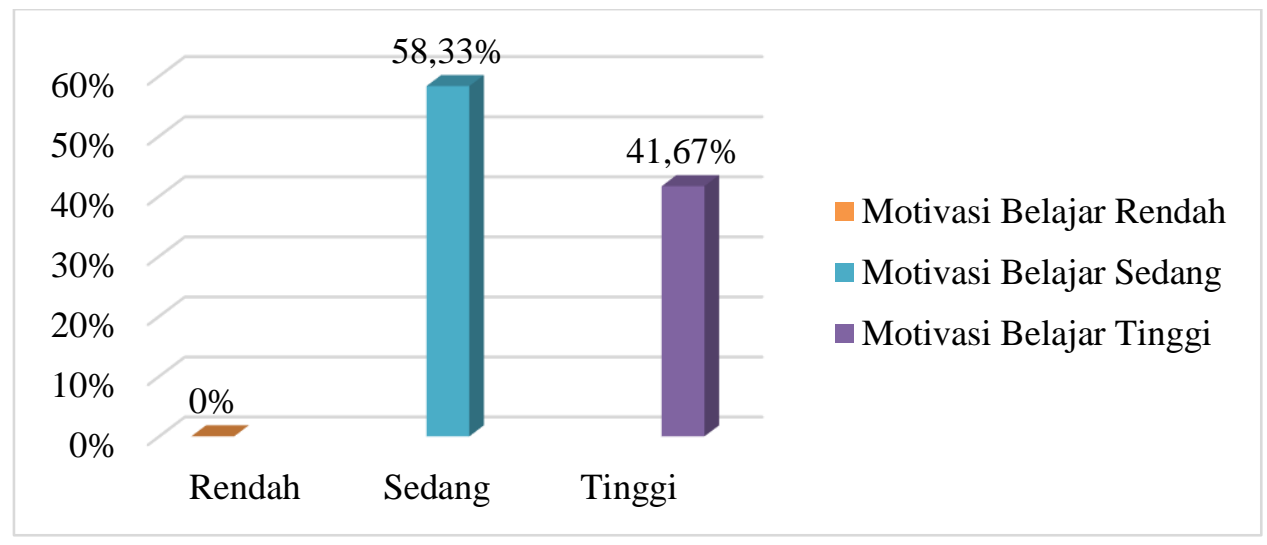

Gambar 1. Diagram Persentase Tingkat Motivasi Belajar

Persentase siswa yang bermotivasi belajar rendah yaitu $0 \%$ atau tidak ada siswa yang memiliki motivasi belajar rendah. Persentase siswa yang memiliki motivasi belajar sedang yaitu 58,33\% atau sebanyak 21 siswa. Persentase siswa yang memiliki motivasi belajar tinggi yaitu 41,67\% atau sebanyak 15 siswa. Tingkat motivasi belajar siswa kelas XI MIPA 3 di MAN 9 Jakarta didominasi oleh siswa yang bermotivasi belajar sedang.

\section{Hasil Kemampuan Representasi Matematis}

Perwakilan subjek yang akan dianalisis kemampuan representasi matematis yaitu MS dan MT yang berada di tabel 3. Berikut ini adalah perwakilan siswa yang memiliki motivasi belajar sedang dan tinggi:

Tabel 3. Daftar Perwakilan Siswa Motivasi Belajar Sedang dan Tinggi

\begin{tabular}{|c|c|c|}
\hline Subjek & Skor & Tingkatan Motivasi Belajar \\
\hline MS (Motivasi Sedang) & 104 & Sedang \\
\hline MT (Motivasi Tinggi) & 124 & Tinggi \\
\hline
\end{tabular}

\section{Siswa dengan Motivasi Belajar Sedang}

Siswa yang memiliki motivasi belajar sedang yaitu MS dengan skor motivasi belajar 104. Di bawah ini adalah jawaban siswa MS dengan motivasi belajar sedang terhadap soal uraian irisan dua lingkaran: 


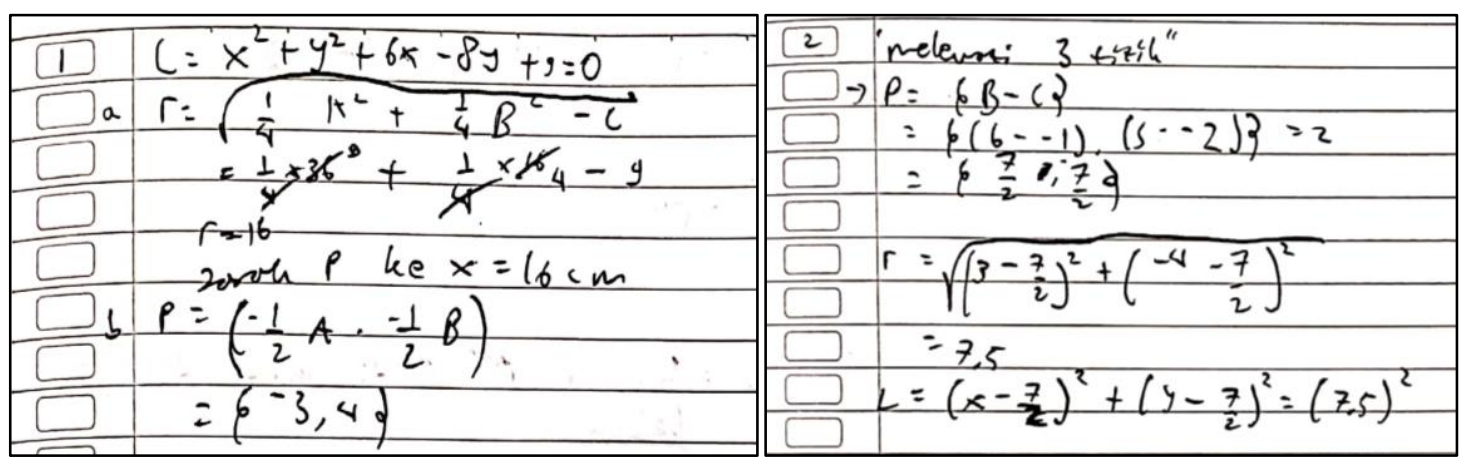

Gambar 2. Hasil Jawaban MS Nomor 1 dan 2

Dari gambar 2, subjek MS mampu mempresentasikan jawaban nomor 1 pada representasi simbolik (ekspresi matematis) dengan baik sesuai dengan indikator representasi simbolik yakni melibatkan ekspresi matematis dalam menyelesaikan masalah. Namun ada kekeliruan di akhir perhitungan dalam memproleh jawaban. MS salah dalam menghitung jari-jari karena menyantumkan akar hanya di rumus saja, tidak ke perhitungan berikutnya. Walaupun ada kesalahan perhitungan, MS menjawab soal dengan rumus yang benar serta proses pengerjaannya benar. Pada hasil wawancara, MS juga dapat menjelaskan dengan baik jawaban hasil pengerjaannya. Faktor ketidaktelitian MS menjadi sebab utama kesalahan perhitungan.

Untuk nomor 2 terkait kemampuan representasi verbal (kata-kata), MS belum memenuhi indikator representasi verbal sebab tidak menuliskan perhitungan ke dalam langkah-langkah berupa kata-kata melainkan melakukan perhitungan dengan rumus saja. MS juga belum tepat dalam menyelesaikan soal nomor 2. Dari hasil wawancara, MS memahami maksud soal namun tidak mengetahui bagaimana cara menyelesaikannya. Selain itu, MS mengaku, ketika pandemi belajar menjadi susah untuk dimengerti. Faktor ketidakpahaman MS dalam menyelesaikan soal menjadi penyebab utama dalam kesalahan jawaban.
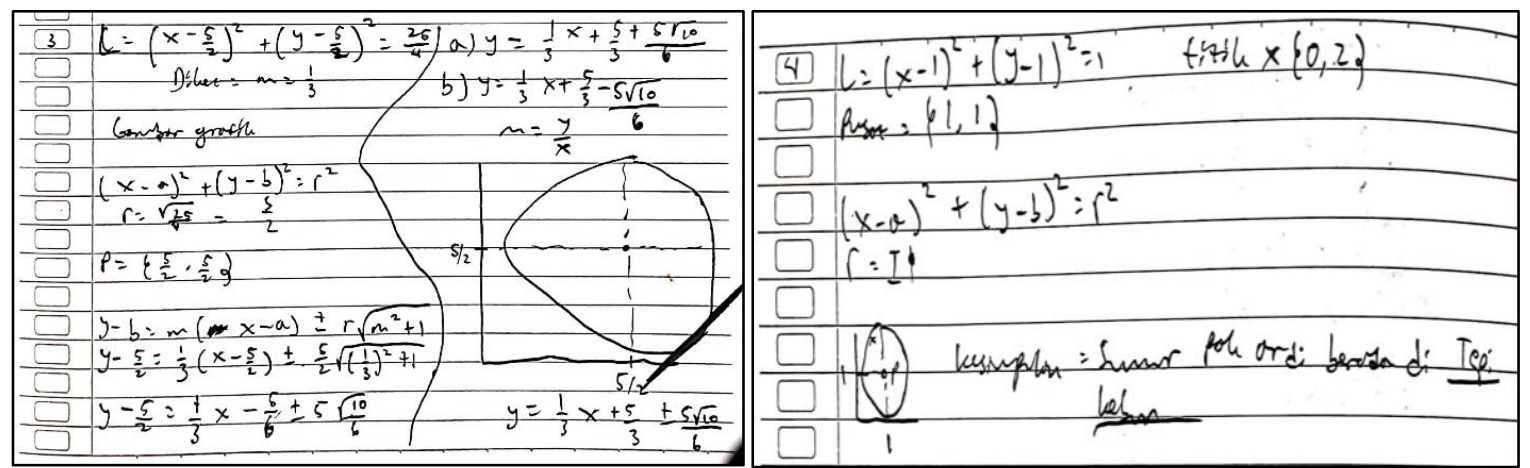

Gambar 3. Hasil Jawaban MS Nomor 3 dan 4

Untuk nomor 3 terkait kemampuan representasi visual (gambar), MS menjawab dengan cukup baik sesuai dengan indikator representasi visual yakni menyelesaikan masalah dengan memanfaatkan visual/gambar. Namun, MS menggambar dengan lingkaran dan satuan yang tidak tepat. Pada hasil wawancara, MS menjelaskan dengan baik hasil pengerjaannya dan mengaku belum terbiasa menggambar 
Analisis Kemampuan Representasi Matematis Siswa berdasarkan Tingkat Motivasi Belajar pada Pandemi Covid-19, Jasmine Salsabila Lutfi, Hikmatul Khusna

dengan menggunakan buku koordinat kartesius agar lebih tepat gambarnya.

Untuk nomor 4 terkait kecenderungan kemampuan representasi matematis yang digunakan, MS menggunakan representasi simbolik, visual, serta memberikan kesimpulan dengan menggunakan representasi verbal. MS menjawab soal nomor 4 proses pengerjaan yang benar, namun MS memberikan kesimpulan yang kurang tepat karena kesalahan dari gambar yang dibuat. Selain itu, MS menggambar dengan kurang simetris dan peletakan koordinat sumur yang salah. Berdasarkan hasil wawancara, subjek MS mengaku lebih cenderung menggunakan representasi simbolik untuk soal uraian. Namun, untuk menjawab soal nomor 4, MS juga memanfaatkan representasi visual dan verbal untuk menyelesaikannya.

\section{Siswa dengan Motivasi Belajar Tinggi}

Siswa yang memiliki motivasi belajar tinggi yaitu MT dengan skor motivasi belajar 124. Di bawah ini adalah jawaban siswa MT dengan motivasi belajar tinggi terhadap soal uraian irisan dua lingkaran:

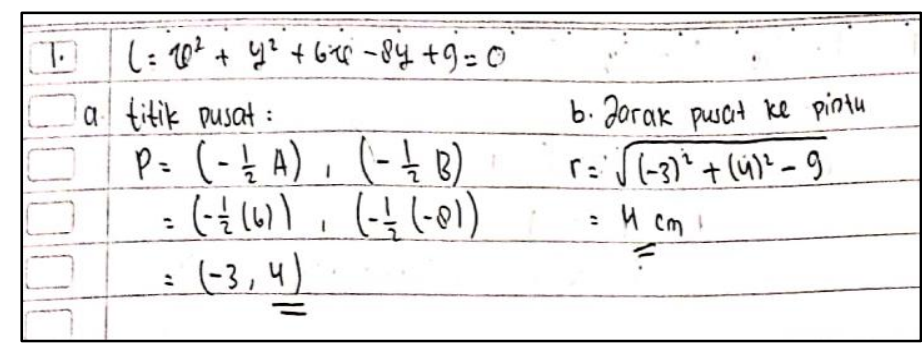

Gambar 4. Jawaban MT Nomor 1

Pada gambar 4, MT dapat mempresentasikan jawaban nomor 1 pada representasi simbolik (ekspresi matematis) dengan sangat baik sesuai dengan indikator representasi simbolik yakni melibatkan ekspresi matematis dalam menyelesaikan masalah. Dalam menjawab soal, MT menggunakan rumus yang benar serta proses pengerjaannya benar. Pada hasil wawancara, MT memahami soal dan menjelaskan dengan sangat baik jawaban hasil pengerjaannya. MT juga mengaku tidak menemui kesulitan pada saat menyelesaikan soal nomor 1 .

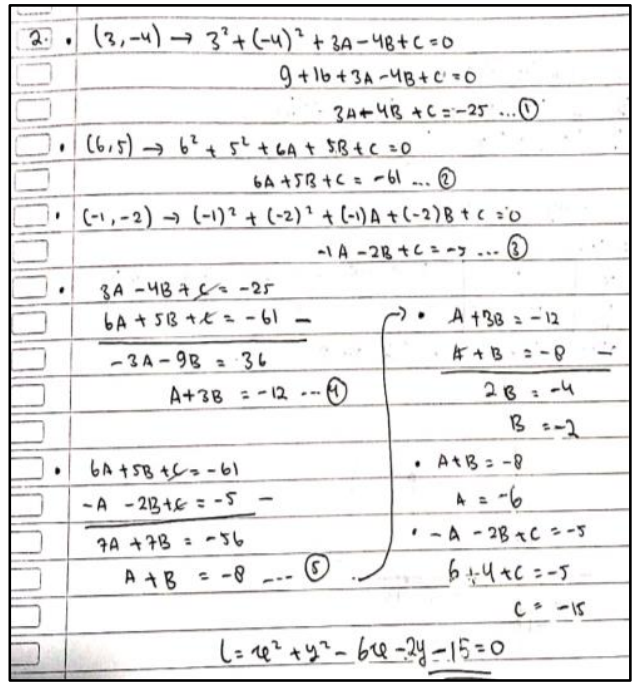

Gambar 5. Jawaban MT Nomor 2 
Untuk nomor 2 terkait kemampuan representasi verbal (kata-kata), MT belum memenuhi indikator representasi verbal sebab tidak menuliskan perhitungan ke dalam langkah-langkah berupa kata-kata melainkan melakukan perhitungan dengan rumus saja. Namun, hasil jawaban MT sudah benar dan langkah-langkah urutannya secara simbolik sudah benar. Dari hasil wawancara, MT mampu menjelaskan dengan sangat baik penyelesaiannya, serta MT tidak menemukan kesulitan dalam menyelesaikan soal. Dari wawancara, MT mengaku tidak menyadari bahwa langkah-langkahnya harus dituliskan dengan katakata. Dalam hal ini, faktor ketidaktelitian MT membaca perintah soal menjadi penyebab utama MT tidak menggunakan representasi verbal.

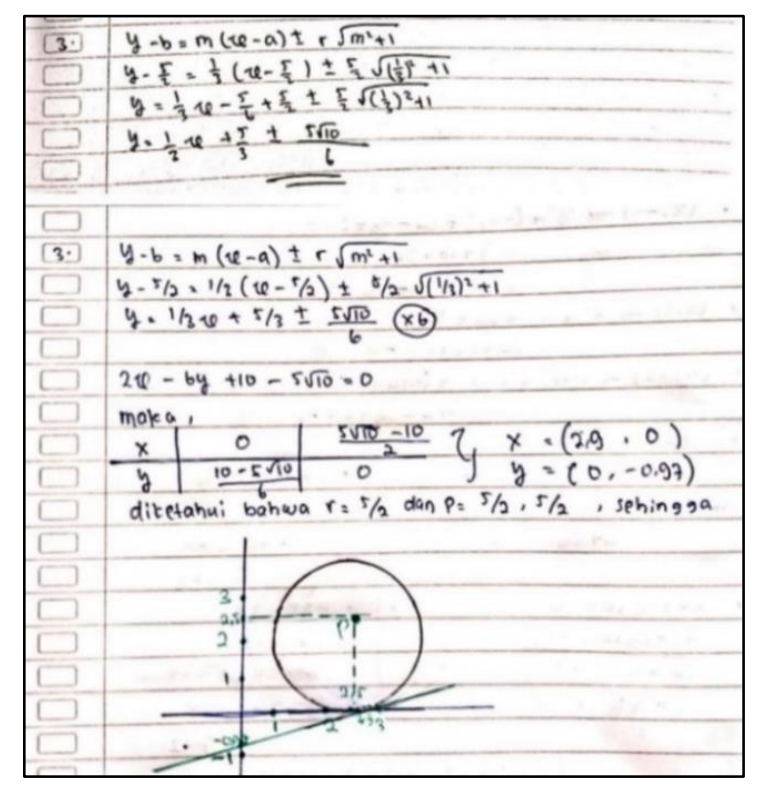

Gambar 6. Hasil Jawaban MT Nomor 3

Untuk nomor 3 terkait kemampuan representasi visual (gambar), MT menjawab dengan baik sesuai dengan indikator representasi visual yakni menyelesaikan masalah dengan memanfaatkan visual/gambar. MT menggambar dengan baik dengan mempersiapkan koordinat-koordinat yang diperlukan dalam menggambar. Pada hasil wawancara, MT dapat memahami maksud soal dan menjelaskan penyelesaiannya dengan sangat baik. MT mengaku kesulitan yang dialami dalam soal nomor 3 yaitu mencari titik yang pas dalam koordinat kartesius di buku tulis, dan mencari titik-titik bantu yang hasilnya akar, sehingga menjadi tantangan MT untuk mencari angka dari hasil akar agar dapat menggambar lingkaran. Dari kesulitan yang dialami MT pada soal nomor 3, MT tetap berusaha untuk bisa menyelesaikan soalnya.

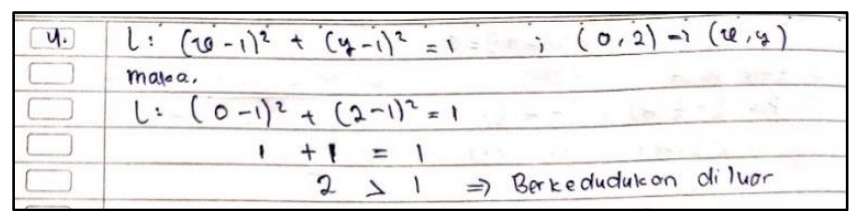

Gambar 7. Hasil Jawaban MT Nomor 4 
Untuk nomor 4 terkait kecenderungan kemampuan representasi matematis yang digunakan, MT menggunakan representasi simbolik dalam menyelesaikan permasalahan dan memberikan kesimpulan akhir berupa kata-kata. MT menjawab soal nomor 4 dengan benar dan proses pengerjaan yang benar. Berdasarkan hasil wawancara MT mengaku lebih suka menggunakan representasi simbolik, jika merasa ragu-ragu dengan jawabannya maka MT juga memanfaatkan representasi visual untuk mengecek jawabannya.

\section{Diskusi}

Pengambilan data riset di MAN 9 Jakarta kelas XI MIPA 3 sebanyak 36 siswa dengan perwakilan subjek MS (Motivasi Sedang) dan MT (Motivasi Tinggi) untuk dianalisis kemampuan representasi matematisnya. Dari hasil analisis jawaban serta wawancara dari 2 subjek, kemampuan representasi matematis siswa bermotivasi belajar tinggi (MT) lebih baik dari siswa bermotivasi belajar sedang (MS). Pada siswa dengan motivasi belajar tinggi (MT) mampu menyelesaikan seluruh soal dengan benar dan baik. Sedangkan siswa dengan motivasi belajar sedang (MS) cukup baik dalam mengerjakan soal representasi matematis karena adanya ketidaktelitian, kurang memahami materi irisan dua lingkaran, kesalahan pengambilan kesimpulan, serta gambar yang kurang sesuai. Hasil riset tersebut selaras dengan riset sebelum mewabahnya pandemi Covid-19 dari Yenni \& Sukmawati (2020) bahwa mahasiswa bermotivasi belajar tinggi dapat menyelesaikan soal representasi matematis pada statistika dengan baik sesuai yang diharapkan. Sedangkan mahasiswa bermotivasi belajar sedang ditemukan kurang teliti dalam menyelesaikan soal.

Dapat dilihat pada indikator representasi simbolik, kemampuan representasi matematis siswa dengan motivasi belajar tinggi (MT) mampu menjawab soal dengan ekspresi matematis dan proses yang benar. Pada indikator representasi verbal, MT belum mampu menyelesaikan soal dengan menuliskan ke dalam kata-kata namun hasil dan urutan pengerjaannya sudah tepat. Dari wawancara, MT mengaku tidak menyadari bahwa langkah-langkahnya harus dituliskan dengan kata-kata. Salah satu penyebab faktor terjadinya kesalahan jawaban karena siswa tidak memahami soal (Anwar \& Hidayani, 2020). Terakhir untuk indikator representasi visual, MT mampu menggambar dengan sangat baik walaupun menemui kesulitan untuk mencari titik bantu koordinat. Hal ini dapat terlihat bahwa siswa dengan motivasi tinggi akan pantang menyerah ketika menghadapi hambatan dan kesulitan belajar (Rahmah et al., 2020). Kecenderungan representasi matematis yang digunakan MT yaitu representasi simbolik.

Pada kemampuan representasi matematis siswa dengan motivasi belajar sedang (MS), untuk indikator representasi simbolik MS mampu untuk menyelesaikan soal dengan ekspresi matematis namun ditemukan kesalahan perhitungan di akhir jawaban. Pada indikator representasi verbal, MS belum mampu menuliskan kata-kata sebagai penyelesaian masalah selain itu MS tidak mengetahui bagaimana cara menyelesaikannya sehingga hasil dan proses pengerjannya belum tepat. Dalam wawancara, MS mengaku ketika pandemi belajar menjadi susah untuk dimengerti. Dalam pembelajaran daring siswa sulit untuk memahami materi karena proses komunikasi siswa kepada guru terbatas (Huzaimah \& Risma, 2021). Terakhir pada indikator representasi visual, MS mampu menggunakan gambar untuk menyelesaikan 
masalah walaupun menggambar dengan lingkaran dan satuan yang tidak tepat. Subjek MS lebih cenderung menggunakan representasi simbolik untuk menyelesaikan masalah.

Kemampuan representasi matematis siswa bermotivasi belajar sedang (MS) dan tinggi (MT) pada pandemi Covid-19, keduanya tidak memenuhi 1 indikator representasi matematis yaitu representasi verbal. Dari hasil analisis jawaban dan wawancara, subjek MS dan MT mengaku jarang menggunakan representasi verbal untuk menyelesaikan masalah. Representasi verbal jarang ditemui karena siswa tidak terbiasa untuk mengunakan representasi verbal (Humairah, 2018). Hasil riset tersebut berlainan dengan riset sebelum mewabahnya pandemi Covid-19 di Indonesia dari Zulfah \& Rianti (2018) bahwa sebagian besar representasi verbal siswa dikategorikan baik karena dapat menuliskan langkah-langkah penyelesaian dengan baik dan teratur. Setelah mewabahnya pandemi Covid-19 ini, adanya kelonggaran interaksi antara siswa dengan guru karena tidak dapat tatap muka secara langsung. Guru ditantang untuk memilih media pembelajaran yang tepat agar proses penyerapan materi oleh siswa dapat berjalan dengan baik.

Kecenderungan representasi matematis yang digunakan siswa bermotivasi belajar sedang (MS), dan tinggi (MT) yaitu representasi simbolik. Hal tersebut tidak mengejutkan karena matematika erat kaitannya dengan penggunaan simbol-simbol matematika. Berlainan dengan hasil riset Suningsih \& Istiani (2021) bahwa ketercapaian indikator representasi visual sebesar 65,2\% yang tertinggi dibanding indikator lainnya pada pandemi Covid-19. Perbedaan kecenderungan representasi matematis siswa dapat dipengaruhi oleh beberapa faktor yaitu seringnya latihan soal berbasis masalah, pemahaman konsep menggambar, serta berlatih menulis secara sistematis (Hadi, 2018).

Representasi matematis yang baik penting dimiliki siswa karena erat kaitannya dengan keberhasilan belajar matematika. Hal tersebut dikarenakan representasi mendukung untuk menemukan penyelesaian dari masalah dengan mengeksternalisasikan sesuatu yang ada di dalam pikiran yang bersifat abstrak (Sanjaya et al., 2018). Jika siswa memiliki kemampuan representasi matematis yang baik maka siswa dapat menemukan penyelesaian dari suatu masalah dengan mudah. Kemampuan representasi matematis memiliki kaitan yang erat dengan motivasi belajar. Jika motivasi belajar siswa tinggi, maka kemampuan representasi matematis juga tinggi. Begitu pun sebaliknya. Kemampuan representasi matematis siswa sangat dipengaruhi oleh motivasi belajar, hal ini dikarenakan motivasi menghasilkan keinginan yang kuat, dorongan keras, serta kecenderungan ingin segera meyelesaikan suatu masalah (Yenni, Sukmawati, 2020). Oleh karena itu, motivasi belajar siswa memiliki peran yang tidak dapat diabaikan untuk keberhasilan kemampuan representasi matematis siswa terutama pada pandemi Covid-19 ini.

\section{KESIMPULAN}

Disimpulkan bahwa tingkat motivasi belajar siswa kelas XI MIPA 3 di MAN 9 Jakarta berada di tingkatan sedang, dan tinggi pada pandemi Covid-19. Motivasi belajar siswa berperan penting untuk keberhasilan belajar matematika siswa, terutama pada pandemi Covid-19 ini dimana pembelajaran dilaksanakan secara daring. Kemampuan representasi matematis siswa bermotivasi belajar tinggi (MT) lebih baik dari siswa bermotivasi belajar sedang (MS). Pada siswa dengan motivasi belajar tinggi (MT) 
mampu menyelesaikan seluruh soal dengan benar dan baik. Sedangkan siswa dengan motivasi belajar sedang (MS) cukup baik dalam mengerjakan soal representasi matematis karena adanya ketidaktelitian, kurang memahami materi irisan dua lingkaran, kesalahan pengambilan kesimpulan, serta gambar yang kurang sesuai. Kemampuan representasi matematis siswa bermotivasi belajar sedang (MS) dan tinggi (MT), keduanya memenuhi 2 indikator representasi matematis dan tidak memenuhi 1 indikator representasi matematis yaitu representasi verbal. Kecenderungan representasi matematis yang digunakan siswa bermotivasi belajar sedang (MS), dan tinggi (MT) yaitu representasi simbolik. Dari hasil riset ini, peneliti mengemukakan saran untuk guru agar dapat mengembangkan representasi verbal siswa saat menyelesaikan masalah pada proses pembelajaran matematika secara daring ini sehingga dapat membantu siswa untuk lebih memahami konsep, serta menyelesaikan masalah dengan representasi matematis yang lebih beragam.

\section{UCAPAN TERIMA KASIH}

Peneliti ucapkan terima kasih untuk keluarga yang memberikan doa dan semangat, selanjutnya dosen pembimbing Hikmatul Khusna, M.Pd. yang selalu membimbing peneliti, validator ahli Asih Miatun, M.Pd., Leni Marlena, M.Si., dan Sunarya, S.Pd. yang telah memvalidasi instrumen riset, kepala madrasah, wakil kurikulum, guru matematika peminatan MAN 9 Jakarta, serta semua pihak yang sudah mendukung serta berkontribusi dalam riset ini sehingga dapat terlaksana dengan baik, dan lancar.

\section{REFERENSI}

Anwar, Z., \& Hidayani. (2020). Analisis Kesalahan Siswa SMP Kelas VIII dalam Menyelesaikan Soal Lingkaran. Mercumatika: Jurnal Penelitian Matematika Dan Pendidikan Matematika, 4(2), 71-79. https://doi.org/10.26486/jm.v4i2.1162

Ayu, G. F. L., Koryati, D., \& Jaenudin, R. (2019). Analisis Motivasi Belajar Peserta Didik Kelas X Program Lintas Minat pada Mata Pelajaran Ekonomi di SMA Negeri 16 Palembang. Jurnal Profit, 6(1), 69-79. https://doi.org/10.36706/jp.v6i1.7876

Cahyani, A., Listiana, I. D., \& Larasati, S. P. D. (2020). Motivasi Belajar Siswa SMA pada Pembelajaran Daring di Masa Pandemi Covid-19. Jurnal Pendidikan Islam, 3(01), 123-140. https://doi.org/10.37542/iq.v3i01.57

Hadi, S. (2018). Representasi Matematis Pemahaman Geometri Siswa MI. Ibriez : Jurnal Kependidikan Dasar Islam Berbasis Sains, 3(2), 87-98. https://doi.org/10.0.82.162/ibriez.v3i1.47

Handayani, R. D. (2017). Analisis Motivasi Intrinsik dan Ekstrinsik Mahasiswa Calon Guru Fisika. Jurnal Kependidikan, 1(2), 320-333. https://doi.org/10.21831/jk.v1i2.8449

Herdiman, I., Jayanti, K., Pertiwi, K. A., \& Naila N., R. (2018). Kemampuan Representasi Matematis Siswa SMP pada Materi Kekongruenan dan Kesebangunan. Jurnal Elemen, 4(2), 216. https://doi.org/10.29408/jel.v4i2.539

Hima, L. R. (2017). Pengaruh Pembelajaran Bauran (Blended Learning) terhadap Motivasi Siswa pada 
Materi Relasi dan Fungsi. JIPMat, 2(1), 36-42. https://doi.org/10.26877/jipmat.v2i1.1479

Humairah. (2018). Analisis Representasi Visual Siswa SMA dalam Memecahkan Masalah Geometri.

Published Thesis. Malang: Universitas Muhammadiyah Malang. Retrieved from http://eprints.umm.ac.id/id/eprint/43191

Huzaimah, P. Z., \& Risma, A. (2021). Hambatan yang Dialami Siswa dalam Pembelajaran Daring Matematika pada Masa Pandemi COVID-19. Jurnal Cendekia: Jurnal Pendidikan Matematika, 05(01), 533-541.

Kementerian Pendidikan dan Kebudayaan Republik Indonesia. (2020). Surat Edaran Nomor 4 Tahun 2020; Pelaksanaan Kebijakan Pendidikan dalam Masa Darurat Penyebaran Coronavirus Disease (COVID-19). Retrieved from https://www.kemdikbud.go.id/main/blog/2020/03/se-mendikbudpelaksanaan-kebijakan-pendidikan-dalam-masa-darurat-penyebaran-covid19

Khairunnisa, Firdaus, M., \& Oktaviana, D. (2020). Analisis Kemampuan Representasi Matematis berdasarkan Motivasi Belajar Siswa di Kelas VII SMPIT Al-Mumtaz Pontianak. Jurnal Prodi Pendidikan Matematika (JPMM), 2(1), 71-80.

Mustangin. (2015). Representasi Konsep dan Peranannya dalam Pembelajaran Matematika di Sekolah. JPM : Jurnal Pendidikan Matematika, 1(1), 15. https://doi.org/10.33474/jpm.v1i1.405

NCTM. (2000). Principles and Standards for School Mathematics. In NCTM. United States of America: The National Council of Teachers of Mathematics, Inc. Retrieved from https://www.nctm.org/uploadedFiles/Standards_and_Positions/PSSM_ExecutiveSummary.pdf

Nirfayanti, \& Nurbaeti. (2019). Pengaruh Media Pembelajaran Google Classroom dalam Pembelajaran Analisis Real terhadap Motivasi Belajar Mahasiswa. Jurnal Penelitian Matematika Dan Pendidikan Matematika; Proximal, 2(1), 50-59. https://doi.org/https://doi.org/10.30605/2615-7667.211

Rahmah, A. T., Aniswita, \& Fitri, H. (2020). Pengaruh Motivasi Belajar Siswa terhadap Kemampuan Pemecahan Masalah Matematika Siswa di Kelas VIII MTSN 3 Agama Tahun Pelajaran 2018 / 2019. Jurnal Ilmiah Pendidikan Matematika AL-QALASADI, 4(1), 56-62. https://doi.org/10.32505/qalasadi.v4i1.1174

Rangkuti, A. N. (2014). Representasi Matematis. Jurnal Forum Paedagogik, 6(1), 110-127. https://doi.org/10.24952/paedagogik.v6i01.168

Sanjaya, I. I., Maharani, H. R., \& Basir, M. A. (2018). Kemampuan Representasi Matematis Siswa pada Materi Lingkaran berdasar Gaya Belajar Honey Mumfrod. Kontinu: Jurnal Penelitian Didaktik Matematika, 2(2), 60-72. https://doi.org/10.30659/kontinu.2.1.72-87

Sugiyono. (2018). Metode Penelitian Pendidikan (Pendekatan Kuantitatif, Kualitatif, dan R\&D). Bandung: Alfabeta.

Suningsih, A., \& Istiani, A. (2021). Analisis Kemampuan Representasi Matematis Siswa. Mosharafa: Jurnal Pendidikan Matematika, 10(2), 225-234. https://doi.org/10.31980/mosharafa.v10i2.984

Surifah, Mustiati, E., Syaifullah, M. Z., \& Bowo, A. N. A. (2016). Pengaruh Motivasi terhadap Minat Mahasiswa Mengikuti Pendidikan Profesi Akuntansi. Jurnal Kependidikan, 46(2), 246-258. 
Analisis Kemampuan Representasi Matematis Siswa berdasarkan Tingkat Motivasi Belajar pada Pandemi Covid-19, Jasmine

https://doi.org/10.21831/jk.v46i2.9615

Yenni, \& Sukmawati, R. (2020). Analisis Kemampuan Representasi Matematis Mahasiswa berdasarkan Motivasi Belajar. Mosharafa: Jurnal Pendidikan Matematika, 9(2), 251-262. https://doi.org/10.31980/mosharafa.v9i2.661

Zulfah, \& Rianti, W. (2018). Kemampuan Representasi Matematis Peserta Didik Bangkinang Dalam Menyelesaikan Soal Pisa 2015. Jurnal Cendekia: Jurnal Pendidikan Matematika, 2(2), 118-127. https://doi.org/10.31004/cendekia.v2i2.56. 